\title{
Performing national identity through Peruvian food migration in Santiago de Chile
}

\author{
WALTER A. IMILAN
}

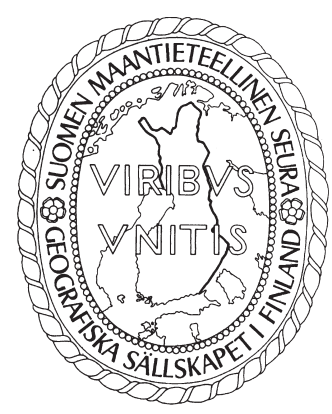

Imilan, Walter A. (2015). Performing national identity through Peruvian food migration in Santiago de Chile. Fennia 193: 2, 227-241. ISSN 1798-5617.

\begin{abstract}
The article explores the processes of re-production of national identity based on food-related practices and discourses of Peruvian migrants living in Santiago de Chile. The meeting point of these three fields - migration, national identity and food - is most evidently performed in the celebration of the Peruvian National Holidays in Santiago. The article finds evidence that the performance in this national festivity reinforces a sense of Peruvianness, thus contributing to the study of contemporary processes of renewal of national identities in transnational contexts. The case study also demonstrates that the ascription of national identity by Peruvian in Santiago is strategic, and it operates as an assemblage of various and locally situated elements.
\end{abstract}

Keywords: migration, national identity, food migration, performance, Santiago de Chile

Walter A. Imilan, Instituto de la Vivienda, Facultad de Arquitectura y Urbanismo, Portugal 85, Santiago, Universidad de Chile, Chile, E-mail:wa.imilan@gmail.com

\section{Introduction}

The presence of Peruvian migrants in the city of Santiago de Chile has become increasingly visible thanks to a booming of food-related businesses such as restaurants and convenience stores. These businesses advertise themselves with a Peruvian image through the display of national symbols like flags, photographs and logos that certify the national origin of their products. Through these references, they have shaped an unprecedented migrant landscape in Santiago (Imilan 2014). Food businesses have become a successful integration strategy for an important sector of the migrant community who rely on displaying a recognizable link to their national origin.

This article explores the ways in which migration, food and national identity intersect in the case of Peruvian migrants in Santiago. Food and the activities surrounding it are not only a resource for economic integration, but also act as a mediating factor in the re-creation of a Peruvian national identity. Peruvian migrants in Santiago indeed use food as a way of performing their national distinctiveness from the host society. In this sense, they clearly reenact the kind of identity process theorized by Goffman (2009) and Bruner (1986), which stress the importance of communication to achieve recognition from 'others', in this case, the host society. This performativity of national identity finds a precise time and space for its execution in the case of Peruvian migrants in Santiago. Since 2012, a series of massive celebrations have taken place in central parts of the city during the Peruvian National Holiday. These weekend festivals follow the concept of culinary festivals, which have become increasingly popular in Peru, mixed with elements taken from Chilean National Holidays. Among all the Peruvian communities abroad, it is only in Santiago that Peruvian migrants have attempted to recreate a sense of national identity by at the same time seeking recognition from the host society.

Food is undoubtedly an important resource in the construction of individual and collective identities (Goody 1982). In contexts of globalization and transnational migrations, food migration understood as the movement of foodstuffs and culinary practices during human migration - opens up a field where multiple geographies intersect; references to what is local, national and global 
are reorganized based on the everyday experience of migrants.

Peruvian migration to Chile has rapidly increased in the last decade. In 2011, over thirty thousand temporary residency visas were granted to Peruvian citizens, thus becoming the largest migrant group, which currently makes up 37\% of Chile's foreign population and close to $2.5 \%$ of the total national population (DEM 2013).

Research on migration to Chile is relatively recent and it focuses on a few specific subjects: feminization processes (Mora 2008; Stefoni \& Fernandez 2011; Tijoux 2013); transnational maternity and care (Acosta 2013; Gonzálvez 2014); use and construction of public and private space (Garcés 2014; Márquez 2014; Imilan 2014); border relations (Lube \& Garcés 2012; Tapia-Ladino 2012); and aspects related to migration and citizenship (Stefoni 2011; Thayer 2013). The food migration field has only been marginally investigated, mainly as economic integration strategies and not as a source for identity construction processes.

The presence of Peruvian migrants in Chile is particularly relevant when one considers that Chile's national identity was founded on a relation based on opposition to the elements of Peruvian culture. The War of the Pacific (1879-1883) played a fundamental role in configuring both national imaginaries - especially in the consolidation of Chilean national identity - bringing about contrasts and differentiations which still persist today (González \& Parodi 2014). The war resulted in the defeat of the allied army of Bolivia and Peru, and the loss of a significant portion of their national territories. Additionally, the Chilean army took possession of Peru's capital city, Lima, for two years (1881-1883).

Chileans have constructed their image as a white, - allegedly European - modern and wealthy society exactly in contrast to Peruvians, who have been regarded in the Chilean imaginary as poor, backwards and indigenous. This outlook still informs all sorts of discriminatory actions and heated nationalist debates in relation to the large presence of Peruvian population in Santiago (Garcés 2014). However, instead of attempting to "blend in" as a means of protection, the Peruvian migrants make themselves visible in the public spaces of Santiago. This is particularly true for activities related to gastronomy. Especially in Santiago's case one can speak of a Peruvian food migration. Peruvian food shops, restaurants and street food vendors have transformed the urban space, giving shape to an unprecedented migration landscape (Stefoni 2008; Imilan 2014).

Certainly, the concept of national cuisine has played a significant role in the construction of imaginaries of national communities since the rise of national states in the nineteenth century (Barlösius 2011). In Peru, in recent years, these culinary practices have influenced the way in which Peruvianness is narrated and performed. At the same time, they have driven a very successful gastronomic industry. Thus, nowadays Peruvian cuisine has become both a marker of national identity and a source of economic development. The government agencies and private associations of gastronomic entrepreneurs, who act as official promoters, have worked together in the formulation and execution of policies aimed at promoting food-related businesses and activities. Thus, they have contributed to the strengthening of a dominant narrative around Peruvian culinary knowledge. Entrepreneurship, sustainable food industry, heritage of food products and local producers have joined forces, achieving international recognition and a prestige status (Lauer \& Lauer 2006). As a result, there has been a significant improvement in the labor perspectives of Peruvians working in this sector both at home and abroad. The emergence of this renewed national narrative has had a deep impact on an important occurrence in Peru's recent history: in the course of the last two decades over $10 \%$ of the country's population has migrated abroad (Sánchez 2012). A strengthened notion of national cuisine now supports the renewal of symbolic and emotional links of the millions of migrants with their country and communities of origin.

This article focuses on the public performance of national identity in relation to food practices. Its main argument is that Peruvian migrants in Santiago construct their national identity by appropriating the official narrative surrounding Peruvian food and cuisine. The migrants take advantage of this narrative as an effective strategy in the negotiation of their multi-sited emplacements resulting from their transnational experiences. The present article illustrates the mechanisms of performing national identity as an assemblage of narratives and practices that are produced in different spaces - national and transnational - and performed in Santiago. Based on an ethnographic account of the celebration of the Peruvian National Holiday in Santiago, the paper reflects on how food plays a major role in understanding the forms of self-representation and recognition of the Peruvian migrant community 
abroad. Furthermore, it explores the re-construction of a national identity as a local process within the context of transnational migrations.

\section{Food and identities}

The relationship between food and processes of identity formation might seem obvious. The statement "we are what we eat" is adequately conceptualized in the idea of 'foodways', which describes the feeding practices that interlock with the culture, tradition and history of different communities. Classical anthropologists such as Malinowski (1985) or Boas (1987) approached food practices as central elements in the understanding of group solidarity. Harris (1984) focused on the ways in which societies generate their nourishment standards based on their relationship with the environment (natural resources, climate, etc.). According to Douglas (2002) the religious distinction between 'pure' and 'impure' hid behind everyday food practices. Lévi-Strauss (1997) went somewhat beyond by stating that food is not just "good for thinking" but also "good for eating". He endeavored to clear up such an inquiry by observing the way cultures work. In fact, the relationship between identity and food is discussed in many research studies, making its multiple roles within culture evident.

Beyond the concerns of anthropology about food, a field of inquiry has recently developed with a strong focus on the commodification of food and cuisines. Classic works on the subject include the biography of sugar by Mintz (1986) which narrates the various episodes that paved the way to the globalization of sugar production in the Caribbean islands. As sugar becomes "good for eating", it builds imaginaries, new relationships, tastes and distinctions, but also commercial, diplomatic and armed conflicts.

The study of food and cuisines is thriving and in recent years it has given birth to an interdisciplinary research field concerned with the relationship between food, globalization and identities (see Watson \& Caldwell 2005; Nützenadel \& Trentmann 2008).

These "food biographies" are ways of explaining local-global connections and the different overlapping agents and actors. The acknowledgment of food as part of an identity repertoire makes room for the conflicts between 'sameness' and 'otherness' in times of economic globalization (Watson \& Cadwell 2005).
Food, as a source of construction of national identities, has been one of the main narratives in the making of imagined communities (Anderson 1993), as described by Elias (2010) in terms of the civilizing power of what and how to eat.

In global contexts, the national is redefined as a contest between diverse geographies. For instance, Wilk (1999) indicates that Belize's cuisine is defined only after contrasting this country with its previous colonial rule, its neighbors and its communities in diaspora. The negotiation between these geographies was furthered by tourism in the young independent State, which demanded a national specificity to its culinary culture. One of the characteristics of a narrative linked to food is that it is embodied. In other words, it becomes part of an individual through the body and the sensitive mediations that consolidate memories (Sutton 2001). In this sense, food and the construction of a notion of 'home' are, in many cases, inseparable (Cieraad 2006).

Food has an unconscious force, in the non-discursive sense, as the construction of identity implies high levels of subjective appropriation for its sensitive internalization. At the same time, food is 'designed' to be shared, to communicate difference. This is how its performative strength is generated. This is also what commonly takes place with migrant populations that arrange their culinary practices as spaces of communication and recognition. In this sense, the so-called "ethnic restaurants" (Möhring 2012) are spaces where local clients are taken on a sensory voyage to a foreign place. They present themselves as a 'fragment' of the foreign culture that co-inhabits in the city and enriches its consumers by broadening their sensitive repertoires. Although the dishes offered in these types of restaurants are often adapted to local tastes, the issue here is not whether a particular dish is genuine or not, but to understand the whole process as a form of communication, of setting the stage for difference. Gastronomy is, in this sense, a source of cultural performance.

\section{Peruvian national identity, national food narrative}

Peru is currently experiencing a gastronomical boom. This process was consolidated during the mid-1990s, encouraged by major transformations in the culinary production derived from its interna- 
tionalization. Mirko and Vera Lauer (2006) call it a "gastronomic revolution" and characterize it as a series of changes which took place both within Peru and abroad: changes in the "techniques, tastes, ingredients, business attitudes, professional cultures, consumers' participation, local and international recognition, academic research, the recovery of historical and regional heritage, editorial impulse and presence on the public space" (Lauer \& Lauer 2006: 15). For these authors, these changes were made possible by the revaluation of the existing cuisine and the discovery of the ancient one. This took place simultaneously with the emergence of young chefs of the haute cuisine coming from the upper class families of Lima.

The 1990s was the decade in which Peru opened up to the world, as a result of neoliberal policies, while at the same time it marked the beginning of the Peruvian diaspora. In this context, Peruvian cuisine became a link between migrants and their communities of origin (Altamirano 2000). A sense of nostalgia led to the popularization of certain basic products of the Peruvian diet. Nevertheless, as mentioned earlier, for most of these migrants, food remains a private affair.

The Peruvian cuisine boom mainly refers to a haute cuisine segment. Its main characteristic is the appropriation of Andean and Amazonian food products that are considered to be 'traditional' and 'native'. These mostly indigenous foodstuffs, strongly linked to their regional consumption, gained status after going "through the hands of cooks with privileged personal stories, who had the possibility of studying in Europe and the United States of America" (Matta 2011: 201). Thus, traditional culinary practices were revalued by these cosmopolitan segments of Peruvian society. There is a marked social class connotation behind the modern construction of the profession and image of the chef as an artist and entrepreneur. His individual talent is a source of social prestige, prestige that is closely linked to his upper class origin. However, this process has trickled down from the higher urban classes down to the popular classes. Matta (2011: 39) confirms that "the experimental and playful impulse or the revaluation of local ingredients are two contributions that come from above and that are subsequently adopted by lower class businesses". This appropriation by the lower classes is the reason why authors have called this a multiregional and multiclass revolution. This call to identity has dug deep in the collective imagination by connecting foods with their cultures of ori- gin and turning them into a reason for pride. External valuation and the appeal of Peruvian cuisine in a more cosmopolitan and globalized context has been fundamental in this process. Matta (2012: 23) observes that "the introduction of Peruvian gastronomy in this cosmopolitan field has expressed itself since the nineties, with the fortunate encounter of a certain amount of native ingredients with international culinary techniques inspired by French Nouvelle Cuisine. The first results set the foundation for a wave that has been called Novoandina (neo-Andean), a term coined by chefs Bernardo Roca Rey and Luis Cucho La Rosa in the eighties". Rodriguez, Peruvian anthropologist, ironically states that this generation of chefs had to use the prefix neo, "...simply because the term Andean had not appealed to the elites of Lima". ${ }^{1}$

Another element that was central in this development was the role played by the expansion of the tourism industry, which transformed Peru, especially with the success of Machu Picchu as a tourist attraction, into a global destination. In fact, gastronomy and tourism have been related to the so-called 'boom' from the beginning. Today tourists attempt to get a taste of local cuisine, but find an offer of international restaurants. Tourism contributed to the development of a high-standard local food offer, encouraging the sophistication of traditional recipes.

The gastronomical boom and its association with a narrative of national identity building can be said to be the product of an assemblage of actors and institutions of the public and private sectors that carry out development projects and proposals on a local, regional and international scale. The initiatives are directed, as stated by Matta (2011: 50), towards "exporting Peruvian Cuisine - or a sophisticated version of it - through the opening of Peruvian restaurants abroad and the systematization of certain types of local or 'native' agricultural production with the objective of guaranteeing the sustainability of a Peruvian culinary-gastronomic system and acknowledging the contribution of rural Andean and Amazonian knowledge and culinary traditions, or attaining UNESCO's recognition as an intangible cultural heritage".

Among the private actors, APEGA (Asociación Peruana de Gastronomía, in Spanish) is undoubtedly the most relevant. It has achieved agreements with ministries, government agencies and universities, and links to agriculture and livestock producers. The association promotes Peruvian gastronomy in all areas of commercial development 
together with other objectives not limited to revenue production, such as campaigning for healthier nutrition or the promotion of agricultural, livestock and hydrobiological resources in an inclusive manner (APEGA/CEPLAN 2012). Their marketing activities reach their highest point each year in Mistura, Lima, the culinary fair that has become well known and grown in importance in recent years, with over half a million visitors in September 2013. ${ }^{2}$ Additionally, during other months they organize a series of regional fairs in which development projects with local farming producers are launched. APEGA has carried out the Alianza Project since 2009, linking cooks and farmers in order to support the articulation of small producers in culinary markets. They have also headed a series of initiatives oriented towards reassessing culinary heritage and launching Lima as a culinary capital within the continent.

A main component of this process has been the education of new cooks through the publication of books and other materials and, most importantly, by directly supporting the development of cooking schools, as in the case of the Pachacútec Cooking Institute. This school aims at reducing the social gap among young cookery students. Educational institutions are expensive and are mostly attended by the middle and higher classes. The Institute was established in Ventanilla, a poverty stricken district of Lima. Not only is the tuition relatively low, but they also benefit the students through links to other international institutes and chefs. Their best ones have access to internships and workshops, for example in European countries like Spain and Italy. A similar case is the Pisco Cooking School in the city of Pisco. These educational initiatives portray an image of Peruvian gastronomy as a space of professional development that enables social mobility for young men and women from disadvantaged classes.

APEGA's intention, judging from the quantity of projects it supports and their broad spectrum, is undoubtedly to transform Peruvian gastronomy to a national industry that integrates different elements into a holistic whole: from the work of agricultural producers in the isolated regions of the country to the exportation of culinary knowledge and practices to more sophisticated global markets.

Among the most important State actors is Promperú (Comisión de Promoción del Perú para la Exportación y el Turismo, in Spanish), a ministerial office in charge of developing a branding strategy, known in Spanish as Marca País, to attract tourism. As part of their job, a series of international promotional videos where Peruvian cuisine plays a major role was created. For example, the first advertisement was named "Peru, Nebraska" ${ }^{3}$, in reference to a small town named Peru located in Nebraska, USA. The spot begins with a bus bearing the colors of the Marca Perú in which Peruvian celebrities arrive at the Midwestern town: actors, actresses and well known chefs from Lima followed by musicians, singers and others. Among the chefs, there are some who have recently been raised to celebrity status. The group is dressed in uniform and headed by Gastón Acurio - an icon of the gastronomic boom, who, not coincidentally, drives the bus. In the spot, the Peruvian guests teach the town inhabitants about their rights as 'Peruvians'. The first right is shouted by one of the chefs: "You live in Peru and have the right to eat delicious food", as the rest of the group displays a variety of Peruvian dishes.

In 2012 a documentary called Peru Sabe: la cocina, arma social (Peru knows/tastes: cuisine as a social weapon) was produced. It covers a visit to Peru by the Catalan chef Ferrán Adriá, famous for revolutionizing the profession through molecular cuisine. According to the script, Adriá is invited to Peru by Gastón Acurio. The whole story seems engineered, more a marketing strategy than a true documentary. The popular Peruvian chef accompanies Adriá as a guide through the country's regions, showing the Catalan chef the diversity of foodstuffs and the wisdom of Peruvian gastronomy. The documentary seems to show how Adriá, from Europe, Old World and cradle of haute cuisine, discovers or re-discovers the wealth of Peru in a metonymical way. The visit ends in the Pachacútec Cooking Institute, where Peru's culinary potential is revealed as a social revolution by enabling social mobility for disadvantaged Peruvian youths. Thus the gastronomic industry is revealed as a complex and integrated strategy for the country's development.

In recent years the alliance between APEGA and State agencies has put forward a series of culinary holidays, such as "Día del Pollo a la Brasa" (Grilled Chicken Day, 2010), "Día del Pisco Sour" (Pisco Sour Day, 2004) "Día Nacional del Ceviche" (National Ceviche Day, 2008), "Año Nacional de la Papa" (National Year of Potatoes, 2008) and "Año Nacional de la Quinoa" (National Year of Quinoa, 2013).

It is important to point out that the relationship between state and food practices is not new in 
Peru. In the 1920s, the Peruvian State promoted the development of so-called restaurantes populares (working class restaurants), meant to offer the emerging working class a diet in accordance with an urban and modern lifestyle. Drinot (2011) researched this institution in the context of modernization and industrialization policies. He observed that the fundamental objective of the project was to promote a society which adapts its cultural program to an idea of modernization, which saw in indigenous cultures its main hindrance. In this way, the restaurantes populares should replace the feeding practices of the indigenous population, but at the same time they were meant to distance the urban population from the growing influence of Chinese restaurants, which already developed as a mass offer for the lower segments of society at that time. ${ }^{4}$ The racist conception of this policy, oriented toward annulling the indigenous and Asian influences on the growing Peruvian urban working class through eating habits, had little impact, according to Drinot. The restaurantes populares never attained the expected popularity and the government did not persevere enough with the project to counteract the dynamics of culture.

This first attempt by the state at policing food was developed as part of an explicit project of the construction of the nation. Many research authors (Aragón 2014; Degregori 2014a) have pointed out that the construction of a Peruvian national identity, conducted by 'white' urban elite, persistently denied the country's indigenous societies during the twentieth century. To be an 'indio' (of indigenous origin) was a stigmatized category, to the point that even the indigenous communities have denied this ascription themselves, replacing it, for example with the concept of 'cholo', a person of racially mixed origin with a distant indigenous past (Bruce 2007). This sustained process of invisibilization of indigenous cultures in Peru explains the lack of a national political project originating from indigenous communities, as has been the case in the last two decades of the twentieth century in neighboring countries like Ecuador or Bolivia (Degregori 2014b).

Although the State has stood behind the implementation of the restaurantes populares and the enactment of the current food policies, there is a fundamental difference in the concept of national identity in both cases. In the 1920s food was meant to play a role in the formation of a modern identity, through the invalidation and replacement of indigenous identities and other cultural influ- ences, Chinese, for example, regarded as threats to this process. Currently, the food campaigns are based on the acknowledgment of Peru's diverse identities, integrating anything from ancestral food preparations (from pre-Incan and Incan times) to the current trends, also mixing the culinary practices of a diversity of cultural influences: indigenous, mestizo, European, Asian. Regional diversity is synthesized as well: products and preparations of distant ecological spaces such as the Andes, the Coast and the Amazon jungle become unified. In fact, the discourse on national identity has changed radically, although the elite in power, consequently responsible for articulating these polices, belongs to the same social groups then and now. In this sense, this new narrative is presented as an apparent 'discovery' of popular food practices by the traditional elites, and the recognition of their economic value in a global context. A discourse is thus constructed around national cuisine that recognizes, values and integrates diversity as a perfect metaphor of contemporary national identity.

In terms of the present research, it is fundamental to point out that Peru's current food campaigns not only strengthen the national identity of Peruvians living in Peru, but also of those living abroad. Thus, gastronomy becomes a key identity reference for Peruvian transnational communities. In this sense, the TV spots of the Marca Perú end with a message to all Peruvians: "Peru is an open brand, we are all called to be its ambassadors". This is a clear invitation to the Peruvian communities abroad. Here is the place where advertising policies related to Peruvian gastronomy intersect with the stories and experiences of migrants in Santiago.

Peruvian migrants not only appropriate these strategies, they also endow them with new meanings, an activity now conceived on a global scale. It is, therefore, not surprising that some authors (Altamirano 2000; Lauer 2012) claim that Peruvian cuisine has become a "cultural icon" for migrant communities, a point of reference for the collective construction of national identities. This is particularly true in Santiago.

\section{Peruvian food marking Santiago}

Peruvian migration to Santiago, especially during the last 15 years, has transformed the urban landscape (Imilan 2014). Currently over eighty thousand Peruvians live in Chile's capital (DEM 2013). Most of them come from the cities and regions of 




Fig. 1. The localization of Peruvian restaurants in Santiago de Chile (March 2013).

the Northern Peruvian Coast, such as Chimbote, Trujillo and Chiclayo, and to a lesser degree, from Lima and its surroundings. There is very little research on migrants originating from the Andean regions of Peru. Despite the lack of official records, we know from other research (Torres \& Hidalgo 2009; Correa et al. 2013) that a large segment earn their livelihood either in construction, in the case of men; or housekeeping jobs, especially among women; or they work as salespeople and in various businesses. There also are some who have a technical and professional education and have had relative success finding work within the healthcare system or private businesses, but little is known about this last group as research tends to concentrate on the more vulnerable populations. A considerable number of people in this migrant community have become gastronomic entrepreneurs and businesspeople, especially within the framework of so-called "nostalgia economies" (Duany 2011) which mark public space. This includes convenience stores offering national products, call centers and, most importantly, restaurants of national Peruvian cuisine.

Figure 1 shows the localization of Peruvian restaurants in Santiago. In the early 1990s, according to restaurant owners interviewed as part of our research, there were only two Peruvian restaurants in Santiago. The next restaurants to open were located in the central sectors of the city. These central districts underwent a serious decay process during the seventies and eighties, a time in which the middle and higher classes migrated to the periphery. The deteriorated city center became available for low cost housing, frequently through informal access. This made room for migrants to settle in these areas, mainly the historic center and the Recoleta and Independencia districts, espe- 
cially after the late 1990s. For many migrants this is the first stop when they arrive in the city. In these districts the Peruvian culinary offer is first oriented towards the Peruvian community itself and then secondly to Chileans. We found that in a second growth stage, during the first decade of the 2000s, the trend was to open new businesses towards the eastern side of the city, where commercial, financial and residential districts with a high rate of consumption of global cuisine are located.

During the months of January and February 2013, an enumeration of Santiago's restaurants was carried out as part of the present research. A team of research assistants ${ }^{5}$ searched different directories and the city's main streets to identify restaurants and pinpoint their locations. In the second stage, the research team focused on the Santiago central area and carried out a detailed search on all streets to further identify Peruvian restaurants and carry out a brief survey in each one of them. We were thus able to put together an approximate map of food businesses existing as of March 2013. Over 300 restaurants were registered during the time of this study.

This study gives a very specific image, within a very specific time frame. This is constantly changing, as observed during and after our research. Some months after its completion, a series of new restaurants in the peripheral sectors of the city, where the middle classes reside, were identified.

During the 1990s, Chile was a recovering democracy and started opening its society to a globalized consumer market. In a way, the rise of Peruvian cuisine went hand in hand with the expansion of more complex leisure offerings in general, with food being one of them.

This increase in Peruvian restaurants managed by migrants seems to be unique when compared with similar cases in other cities, such as in Europe or the United States of America, where employment strategies are usually linked to jobs in the service and agricultural sectors (Altamirano 2000). In these host countries, the food experience remains within the private sphere of family and friends. Isolated entrepreneurial attempts depend on a large initial investment and on expensive publicity campaigns, and are usually destined to open trendy restaurants in exclusive neighborhoods of big cities such as New York or London. ${ }^{6}$ In fact, Peruvian cuisine, in all possible price segments, seems to have found in Santiago its most successful address of all the current destinations of Peruvian migration.
Usually the study of food migration focuses on the so-called ethnic economies. Even though their empirical expression is a matter of great debate, they can generally be defined as economic activities with access restricted to the ascription of a common ethnic origin of its participants. In this manner, migrant cuisines are usually linked to an exclusive economic dimension (Solé \& Parella 2005; Arjona Garrido \& Checa 2007).

The most thoroughly studied Peruvian migration movements are those of people from Andean regions to Lima, within Peru itself (Golte \& Adams 1991; Sandoval 2009). Through strong and flexible social bonds based on extended family, these migrants develop collective strategies in which they re-create an "Andean rationality" characterized by internal solidarity and a tendency to establish their own businesses (Golte 2001).

Santiago presents a different case, beginning with the origins of the migrants who have settled there, as explained above. The networks established by them have been of great importance for the development of this gastronomic industry. In Santiago, we find open, flexible and dynamic networks that are not always based on the structure of the extended family; Chileans and migrants from other Latin American nationalities are often included in these networks (Imilan 2014).

\section{Performing the national through celebration}

The Independence Day celebration in Peru does not have a massive festival character; it is mainly an official celebration of state authorities. Some events of popular character are rare exceptions, such as a parade sponsored by Mr Wong, a supermarket chain, in Lima which takes place a week before the Holiday's date (Ortemberg 2006). However, it has gained a particular meaning for Peruvian migrant communities. In the United States, for example, which hosts the largest Peruvian migrant community, this holiday is celebrated with parades in some big cities. The Peruvian Parade follows the form of other ethnic parades in the USA, based on the Puerto Rican Day Parade, to which it makes a direct reference, or the Saint Patrick's Day Parade of the Irish community, which is the oldest of this type of events in this country (Berg 2005). On the other hand, in Japan, where a large Peruvian community resides, the National Holiday is celebrated in salsa 
music bars catering to the Latin American population. In the cities where the Peruvians gather to celebrate together, Tokyo and Osaka, there is no public expression of this festivity (Rossi 2014). Alternatively, in Santiago the celebration has become a culinary festival, which lasts three days - a sort of carnival, in which food plays a central role both in public and private events. The Chilean National Holidays are a carnivalesque festivity. During the three or more days of celebration, food and music have an important presence. The Peruvian celebration in Santiago seems to mimic the elements of its Chilean counterpart.

On July 2013, Peru's Independence Day was celebrated with two large events in central areas of the city, where music and food abounded. The differences between these two events are many. Traditionally, they are organized yearly by event producers linked to the Peruvian community and to the so-called "nostalgia industry" (product importation, telephone services, etc.). The more traditional of the two events maintains the character of a folk festival, while the second, which is younger, is a broader festival of Latin American migration in Santiago.

These events should be interpreted as social performances, as cultural acts or representations of cultural processes in specific contexts, and also as cultural agencies (Conquergood 1989). From this perspective, they are not just reproductions of a social and cultural universe that has been frozen in the time-space of origin. They are creative processes as well, active in the configuration of identities based on the new contexts and their need to communicate a social and cultural difference to "the Other". Social performances are creative acts in which participants play with values and meanings, re-presenting them; they are spaces to 'think' through identity relations (Bruner 1986; Geertz 1986). In fact, the idea of theatricality that accompanies the concept of performance does not imply that the participants follow a pre-established script, simply carrying out a pre-formulated narrative. It is the actors themselves who determine the internal organization of the event.

In the more traditional event - which first started in 2003 - Santiago's mayor and Peru's ambassador are usually present to salute the visitors. It takes place on Sunday, in a central park of the city and is visited each year by an increasing number of Chileans. Approximately one hundred food stands offer the traditional fare of Peruvian gastronomy. In 2012 it was visited by forty thousand people according to the organizers.

The stands are harmoniously integrated into the park's vegetation, creating open spaces that the visitors use to gather together with their family and friends (Fig. 2). On one side, there is a huge stage, equipped with state-of-the-art concert technology. In general the event is very well organized; all the details seem to have been considered in the context of such a large event.
Fig. 2. Event "Peruvian National Holiday" in Quinta Normal park in Santiago de Chile.

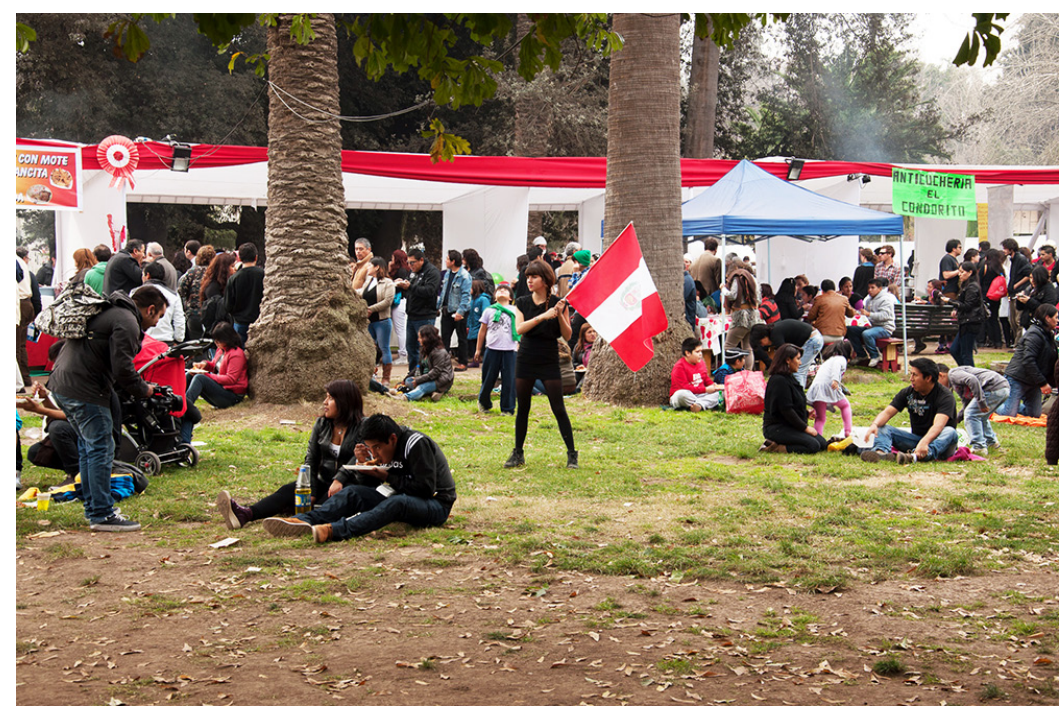


Each of the stands is a small restaurant, equipped with grills and deep fryers. Most of the dishes are prepared beforehand, they only need to be grilled or fried during the festival. The assigned space becomes small between pots, grills, plastic containers full of seasoned foods and the team of kitchen assistants. At noon, the visitors come in and slowly spread around the festival's area, looking for where to have lunch. Around 5 p.m. the space is packed. Long queues of visitors crowd around the stands.

One of these stands is managed by Trinidad, who arrived from Lima 15 years ago. During six years, she worked as a housemaid. Later she opened a small food business in the city center. In her 'cookery' she sells lunch and offers other services such as shipping services from Santiago to Lima; either she or her husband travel themselves to deliver the packages. She has been preparing the whole week for the sales of this one day, with the assistance of five family members who fry, bake and sell different dishes. The majority of the stand owners are small culinary businessmen and businesswomen, who usually manage small cafeterias or sell food on the weekends on street markets, in their own homes or during special events. For example, Beatriz, a woman from Trujillo, has specialized in homemade dishes that are usually served on special occasions and are not available at restaurants. She works as a caregiver for elderly people during the week and on the weekends she offers her catering services. She wishes to consolidate a catering business that specializes in traditional dishes that are hard to find.

During the day of the event, families play a central role in the management of each of the stands. Cooks, salespeople and helpers are all part of the family. Trinidad receives the support of seven families while Beatriz is helped by five.

The festival, simply called "National Peru Day Celebration", has maintained an evident and unequivocal ascription with the Peruvian community and is focused on the cuisine and music of the Peruvian community's popular culture. The food stands are represented by small businesspeople and their families. Most of the bands playing early are non-professional groups of music and dance that are active in Chile; the late evening is reserved for the stars of Peruvian popular and folk music. Without a doubt this event can be considered to be purely Peruvian.

The attendance of Chileans to this event has increased over the years according to the partici- pants themselves. In 2013, Chileans seemed to make up a majority of the visitors, identifiable by their pronunciation and by some elements in their way of dressing. The festivity has transformed a space for the migrant community into an event meant to reach out to the host society.

A good deal of information is presented in a very didactic way: the food stands offer their products under the assumption that the clients have absolutely no knowledge of the greatness of Peruvian cuisine. Whether this is so or not, this way of presenting the dishes heightens the performative character of the event. The lists of ingredients are written clearly in large letters, the origin of some of them is explained, and cooks and helpers are available at all times to give detailed explanations. While accompanying some of our informants in their stands, we observed that Chileans request the dishes that are more common in Santiago's restaurants, while the Peruvian customers consume special recipes that are not available in this market. On this subject, Beatriz, one of our informants, comments: "the carapulcra [a stew composed of many different meats] takes a long time to prepare, that is why Peruvians come here [to the festival]. You will not find it elsewhere, and I am very good at preparing it".

Each stand's cooking capacity is impressive. Trinidad, for example, has purchased over 40 chickens, which allows her to sell at least 140 portions. Furthermore, she offers sweet fried cakes (picarones), grilled meat and beverages. There is no rest amidst the stands, the grilling and frying fires are kept at full intensity throughout the day.

At the center of the field there is a stand selling the shirts of the men's national football team and the women's national volleyball team. Groups of young people buy shirts and then photograph themselves dressed up in them. Businesses linked to transnational migration are also represented with stands. Some examples are pre-paid telephone cards, money transfer and bus transport enterprises. Even one of the buses that travel the Santiago-Lima route (54 hours) is on exhibition right there in the middle of the park.

In the course of the afternoon a diversity of shows is presented on stage, for families and a broad audience. As the evening nears, famous Peruvian performers begin to take to the stage, such as Anita Santibáñez who appears in Andean costumes and is backed up by high-end show production. She sings ballads that narrate stories with which the migrant community can identify: the 


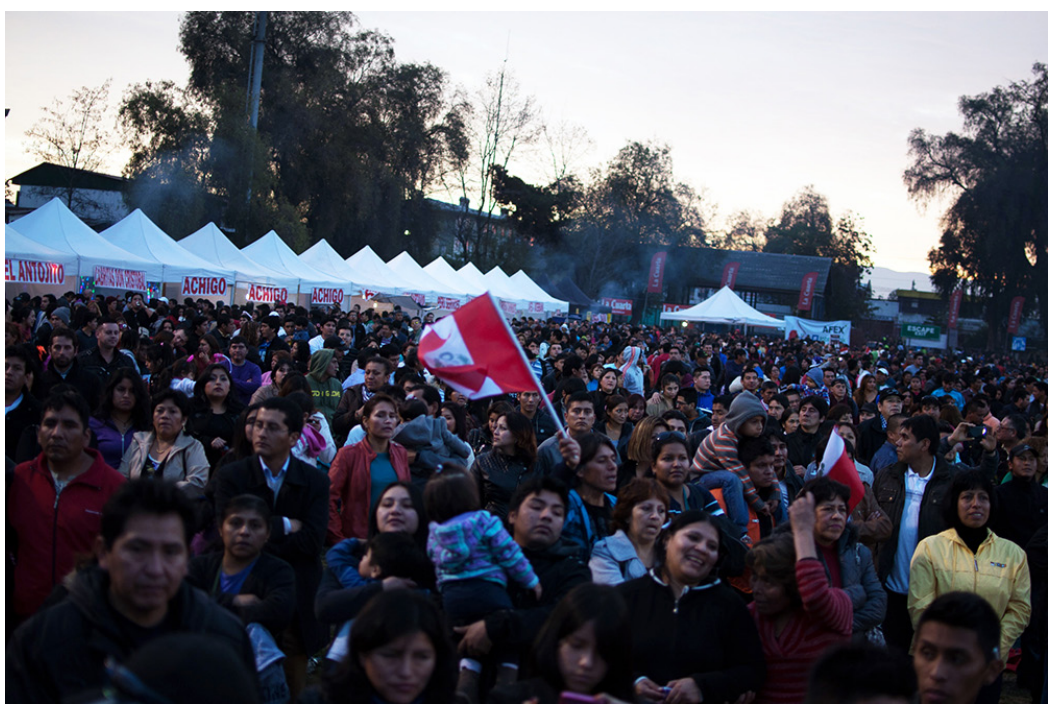

Fig. 3. Event Perú mil sabores at the Recoleta Stadium, 2013, Santiago de Chile. feelings of nostalgia for the town left behind, sadness at the thought of family, women who miss their children, and other themes. Throughout the presentation she greets the people from different towns and cities in Peru. To conclude, the audience sings along with great emotion to the big ballad hits of the evening.

The second and younger event, which takes place in the Recoleta district, is only a thirty minute walk away. In 2013, it was its first edition and it lasted three days with a very well equipped musical program, including well-known artists from Peru as well as from Colombia and Ecuador (representing other two important migrant communities in Chile). Around forty stands were organized in line, on both sides of the soccer field of the Recoleta Stadium, located in one of Santiago's districts with the highest rate of migrant residents. There was a VIP area near the entrance where restaurants from Lima set up representational stands, offering their dishes together with a special selection of elegant restaurants that are located in Santiago. The event's name, Perú, mil sabores (Peru, a thousand flavors), reflects the land's culinary wealth. The showcased restaurants belong to culinary professionals, nevertheless, the massive character of this event is best represented by the musical program (Fig. 3). On the closing day, more than twenty thousand people celebrated in front of a stage of large dimensions.

Musical performances began in the afternoon and they extended until late in the evenings. The bands are usually a selection of commercially successful artists coming from different corners of the continent. This transforms the event into a Latin American celebration and not just a Peruvian one: a celebration of migrants in Santiago.

Each artist salutes his or her people, followed by the rest of the audience. The famous ballad singer Segundo Rosero, from Ecuador, calls out to those coming from cities, such as Quito, Guayaquil and Cuenca, to raise their hands and sing along. He speaks about love and the nostalgia felt by "all those who are far away from home, their family and friends". This Latin American spirit is present in each one of the presentations and in the event's décor, through the use of flags of many countries of Latin America and the presence of a few food stands from Colombia, Ecuador and the Dominican Republic.

There are stands that specialize in the sale of Pisco Sour, a cocktail that has gained great popularity in the city. Its main customers are of Chilean origin. Meanwhile, Peruvians quench their thirst with beer. The managers of these stands have come from Peru exclusively for this festival. They are not the only ones, 22 stands share this same situation, mostly representing Peruvian restaurants. The most successful ones serve grilled meat using techniques unknown to Chileans. In this case, the hungry clients stand in line for up to an hour before being served a portion. Food and drink are relatively expensive, nevertheless, the stands are crowded and 
the visitors eagerly consume the different dishes. Even before the musical program reaches its high point, there is no more food to buy. The event's organization is similar to that of the older festival. The decoration, the way the food is presented and the services follow the same pattern. Some days after the events we interviewed some of the stand owners of both festivals. In general, they all hoped to earn more money, their sales were not as good as expected. Additionally, the stand fees are high. Consequently they all expressed an interest in trying out the other festival next year.

Beyond the differences between both events, they can be seen as cultural performances. Peruvianness is staged as an identity that expresses itself through gastronomy, and gastronomy as an exclusive knowledge of a national community. Peruvian gastronomy has been recognized on a global scale due to its quality, particularity and sophistication. The production and consumption of food develops into an event in which an identity experience is performed. The differences between regional attributes of great importance within Peru are blended together in these events. The stands barely make any reference to them: a national conception, unifying and integrating, governs at all times.

It is undeniable that this process of identity recreation is supported by an entrepreneurial and commercial project. Although there are different types of businesspeople involved, it must be emphasized that it is the job of amateurs - among the migrant population - and not of professionals to put such decorative cultural events together. The migrant population adopts sophisticated aesthetics to present their stands and dishes. They serve, wear uniforms and explain the dishes as if they were professionals from high-end restaurants. These aesthetics and manners comply with a high global culinary standard, such as the one constructed by the official Peruvian discourse. This is a clear example of ordinary people appropriating globalized symbols such as those linked to Peruvian gastronomy. In fact, a great part of the global dynamics generated around Peruvian cuisine has been produced with the aim of supporting a sophisticated concept of entrepreneurship, on a high scale structure of investments. The hundreds of stand owners who participate in these events do not belong to this segment. Nevertheless, they make themselves part of this imaginary of the Peruvian gastronomic world. What the participants do is appropriate the globalized semantics of Peruvian cuisine. In these terms, the makers of these celebrations articulate a sort of popular globalization.
Lins Ribeiro (2009) uses the concept of popular and non-hegemonic globalization to refer to the tactics developed by subaltern groups in order to obtain benefits from the dynamics of global capitalism, especially linked to consumption, which have actually been designed at the core of great economic groups and transnational interests. Similarly, we might say that in these celebrations of Peruvianness the small impresarios make the globalization of Peruvian cuisine as haute cuisine 'popular'. In this sense, migrants find in the appropriation of this image an opportunity to successfully develop their own migratory projects.

\section{Conclusions}

The success of a migrant culinary culture is usually regarded as the success of ethnic economies. Within migration studies, the proliferation of restaurants and activities linked to gastronomy are usually observed as an indicator, an expression of social networks based on the origin of the migrants that encourages business activities as incorporation strategies of the migrant population. Nevertheless, the success of Peruvian gastronomy in Chile is not only due to the development of an economic strategy of migrant incorporation and migrant business culture. It is also due to the fact that, as we have seen in detail, food plays a central role in this re-configuration of migrant identity via the strategic deployment of national markers. In this sense, the text has approached three fields that meet in a particular manner in the case of the Peruvian migrant community in Santiago: migration, food and national identity.

The idea elaborated in this article is that gastronomy becomes a mediator that assembles various processes. On the one hand, there is private and governmental support for Peruvian cuisine as a globalized product oriented towards a market of consumption of haute cuisine, whose innovative potential is globally sustained by relying on a particular national tradition. On the other hand, there are Peruvian migrants who, following rigorous work and business ethics, offer a local product that cannot only be considered exotic or be associated with the "nostalgia consumption" of the migrant community. They develop a cuisine oriented towards the host society as a commercial strategy and as a mechanism of recognition that attempts to transcend the historic relationship of discrimination of Chileans against Peruvians. 
The relationship between gastronomy and national identity is staged and performed, especially during Peru's national holidays. In this context, Peruvianness is both communicated in and through a gastronomic performance which is also a creative process, as identity is being re-thought through culinary practices. By performing and staging Peruvianness in gastronomic ways, Peruvian migrants in Santiago clearly capitalize on their national origin, thus defying the 'invisibility' which often characterizes migrants in hostile societies.

The State's role, together with a group of private businesses, in the construction of a narrative of national identity linked to food possesses special characteristics that enable us to reflect about the importance of National States in the construction of these narratives in globalized contexts. First, these narratives originate from a commercial interest, adopt the semantics of patrimonial policies and are aimed at creating a new market. Secondly, they make room for a transnational policy of identity construction, which concerns itself with the territorialization practices of Peruvian communities abroad.

This article shows how the public production of food migration, anchored in a conception of national identity, results in a phenomenon of various dimensions: from the economic integration and transformation of urban landscapes to the influence on recognition strategies and, above all, the renewal of a narrative of national identity that is now being re-signified and re-appropriated through the experience of transnational migration.

\section{NOTES}

1 Personal communication with Humberto Rodríguez, Professor at the Department of Anthropology in Universidad Nacional Mayor San Marcos, Lima September 15th 2013.

${ }^{2}$ In http://www.apega.pe/contenidoc/noticiasC4.htm/. 3 Official video: https://www.youtube.com/ watch? $v=8 j o X / w K M k r k$.

${ }^{4}$ On Chinese migration and food practices in Peru, see Rodríguez (2006).

${ }^{5}$ The team was formed by anthropology students of the Alberto Hurtado University, Santiago de Chile, under the direction of the author of the present article.

${ }^{6}$ Entrepreneur Gastón Acurio has recently opened some restaurants in big cities in the United States of America, supported by important investments and marketing campaigns. Also, Martín Morales has attracted the attention of lifestyle media to his relatively new restaurant in the Soho neighborhood of Lon- don. Meanwhile, in Berlin, Enrique Serván works towards establishing Peruvian cuisine within the city's culinary map.

\section{ACKNOWLEDGEMENTS}

This research was supported by FONDECYT $\mathrm{N}^{\circ}$ 11121539 "La experiencia con la comida peruana en Santiago de Chile. Prácticas de identidad y espacio de la migración transnacional peruana" (CONICYTCHILE).

\section{REFERENCES}

Acosta E 2013. Mujeres migrantes cuidadoras en flujos migratorios sur-sur y sur-norte: expectativas, experiencias y valoraciones. Polis. Revista Latinoamericana 12: 35, 35-62.

http://dx.doi.org/10.4067/S0718-65682013000200003.

Altamirano T 2000. Liderazgo y organizaciones de peruanos en el exterior: culturas transnacionales e imaginarios sobre el desarrollo. Fondo Editorial PUCP, Lima.

Anderson B 1993. Comunidades imaginadas: reflexiones sobre el Origen y la Difusión del Nacionalismo. Fondo de Cultura Económica, México.

APEGA/CEPLAN 2012. Gastronomía peruana al 2021. Lineamientos para un programa de desarrollo de la gastronomía peruana en el marco del Plan Bicentenario. Centro nacional de Planeamiento Estratégico, Lima.

Aragón J 2014. Los estudios políticos en el Instituto de Estudios Peruanos: cambios, continuidades y posibilidades. In Tanaka M (ed). 50 años pensando el Perú: una reflexión crítica, 239-272. IEP, Lima.

Arjona Garrido Á \& Checa J C 2007. Ethnic economy. Theories, concepts and new advances. Revista Internacional de Sociología 64: 45, 117-143.

Barlösius E 2011. Soziologie des Essens: eine sozialund kulturwissenschaftliche Einführung in die Ernährungsforschung. Beltz Juventa, Frankfurt.

Berg U 2005. ¿Enmarcando la «peruanidad»? La poética y pragmática de un espectáculo público entre los migrantes peruanos de Nueva Jersey. In Berg U \& Paerregaard K (eds). El Quinto Suyo. Transnacionalidad y formaciones diaspóricas en la migración peruana, 37-68. IEP, Lima.

Boas F 1987. Anthropology and modern life. Dover Publications, New York.

Bruce J 2007. Nos habíamos choleado tanto. Psicoanálisis y racismo. Fondo Editorial de la Universidad San Martín de Porres, Lima.

Bruner E M 1986. Experience and its expressions. In Turner $\mathrm{V}$ (ed). The anthropology of experience, 3-30. University of Illinois Press, Chicago.

Cieraad I 2006. At home: an anthropology of domestic space. Syracuse University Press, New York. 
Conquergood D 1989. Poetics, play, process, and power: The performative turn in anthropology. Text and Performative Quartely 1:1, 82-95.

Correa V, Bortolotto I \& Musset A (eds). 2013. Geografías de la espera. Migrar, habitar y trabajar en la ciudad de Santiago. 1990-2012. Uqbar, Santiago.

Degregori Cl 2014a. El estudio del "otro». Cambios en los análisis de etnicidad en el Perú. In Degregori $\mathrm{Cl}$ (ed). El aprendiz de brujo y el curandero chino, 103-126. IEP, Lima.

Degregori Cl 2014b. Estados nacionales, etnicidad y democracia en América Latina. In Degregori Cl (ed). El aprendiz de brujo y el curandero chino, 207-212. IEP, Lima.

DEM Departamento de Extranjería y Migración 2013. Ministerio del Interior y Seguridad Pública, Chile. <http://www.extranjeria.gob.cl/quienes-somos/ estadisticas-migratorias/>. 22.09.2014.

Drinot $P$ 2011. The allure of labor. Workers, race and the making of the Peruvian state. Duke University Press, Durham.

Douglas M 2002. Purity and danger: an analysis of concepts of pollution and taboo. Taylor, New York.

Duany J 2011. Blurred borders: transnational migration between the Hispanic Caribbean and the United States. The University of North Carolina Press, Chapel Hill.

Elias N 2010. Über den Prozess der Zivilisation: soziogenetische und psychogenetische Untersuchungen. Zweiter Band: Wandlungen der Gesellschaft: Entwurf zu einer Theorie der Zivilisation. Suhrkamp Verlag, Frankfurt.

Garcés A 2014. Comercio ambulante, agencia estatal y migración: crónica de un conflicto en Santiago de Chile. In Imilan W, Garcés A \& Margarit D (eds). Poblaciones en movimiento. Etnificación de la ciudad, redes e integración, 147-167. Ediciones Alberto Hurtado, Santiago de Chile.

Geertz C 1986. Making experiences, authoring selves. In Turner V \& Bruner E (eds). The anthropology of experience, 373-380. University of Illinois Press, Chicago.

Goffman E 2009. La presentación de la persona en la vida cotidiana. Amorrortu Editores, Buenos Aires.

Golte J 2001. Cultura, racionalidad y migración andina. IEP, Lima.

Golte J \& Adams N 1991. El Caballo de Troya de los invasores. Estrategias campesinas en la conquista de la Gran Lima. IEP, Lima.

González S \& Parodi D 2014. Introducción. In González S \& Parodi D (eds). Las historias que nos unen. Episodios positivos en las relaciones peruana-chilenas, siglos XIX y XX, 3-25. RIL Editores, Santiago.

Gonzálvez H 2014. Repensar la sexualidad desde el campo migratorio: una etnografía multisituada sobre parejas heterosexuales migrantes colombianas. Revista Estudios Sociales 49, 101-112. http://dx.doi.org/10.7440/res49.2014.08.

Goody J 1982. Cooking, cuisine and class: a study in comparative sociology. Cambridge University Press, UK.
Harris M 1984. Vacas, cerdos, guerras y brujas. Alianza editorial, Madrid.

Imilan WA 2014. Restaurantes peruanos en Santiago de Chile: construcción de un paisaje de la migración. Revista de Estudios Sociales 48, 15-28. http://dx.doi.org/10.7440/res48.2014.02.

Lauer M 2012. La olla de cristal. Mirando el futuro de la cocina peruana. Universidad San Martín de Porres, Lima.

Lauer M \& Lauer V 2006. La revolución gastronómica peruana. Universidad de San Martin de Porres, Lima.

Lévi-Strauss C 1997. The culinary triangle. In Counihan C \& Esterik P V (eds). Food and culture: a reader, 28-35. Routledge, NYC.

Lins Ribeiro G 2009. La globalización popular y el sistema mundial no-hegemónico. Nueva Sociedad 241, 36-62.

Lube M \& Garcés HA 2012. Mujeres peruanas en las regiones del norte de Chile: apuntes preliminares para la investigación. Estudios atacameños 44, 5-34. http://dx.doi.org/10.4067/S0718-10432012000200002.

Malinowski B 1985. Crime and custom in savage society. Rowman \& Littlefield Publishers, Totowa, NJ.

Márquez F 2014. Inmigrantes en territorios de frontera: La ciudad de los otros. Santiago de Chile. EURE (Santiago) 40: 120, 49-72. http://dx.doi.org/10.4067/S0250-71612014000200003.

Matta R 2011. Posibilidades y límites del desarrollo en el patrimonio inmaterial. El caso de la cocina peruana. Apuntes 24: 2, 196-207.

Matta R 2012. Cocinando una nación de consumidores: El Perú como marca global. Revista Consensus 17: 1, 49-60.

Mintz SW 1986. Sweetness and power: the place of sugar in modern history. Penguin Books, New York.

Mora C 2008. Globalización, Género y Migraciones. Polis (Santiago) 7: 20, 285-297.

Möhring M 2012. Fremdes Essen: die Geschichte der ausländischen Gastronomie in der Bundesrepublik Deutschland. Oldenbourg Wissenschaftsverlag, Oldenbourg.

Nützenadel A \& Trentmann F (eds). 2008. Food and globalization. Consumption, markets and politics in the modern world. Berg Publishers, London.

Ortemberg P 2006. El caleidoscopio de la efeméride patria y sus proyecciones en la esfera pública: «Bienvenido Sr Wong». In Cánepa G \& Ulfe M (eds). Mirando la esfera pública desde la cultura en el Perú, 51-77. CONCYTEC, Lima.

Rodríguez H 2006. La pasión por el chifa. Nueva Sociedad 203, 79-88.

Rossi E 2014. Noche de Baile / A dancing night: immigrants, transnationalism, and music in Japan. In Irazábal C (ed). Transbordering Latin Americas: liminal places, cultures, and powers (t)here, 258277. Routledge and Taylor \& Francis Group, New York.

Sánchez A 2012. Perfil migratorio del Perú 2012. Organización Internacional de las Migraciones, Lima.

Sandoval P 2009. Los rostros cambiantes de la ciudad: cultura urbana y antropología urbana en el 
Perú. In Degregori Cl (ed). No hay país más diverso. Compendio de antropología peruana, 278330. Red para el Desarrollo de las Ciencias Sociales en el Perú, Lima.

Solé C \& Parella S 2005. Negocios étnicos: los comercios de los inmigrantes no comunitarios en Cataluña. Cidob, Barcelona.

Stefoni C 2008. Gastronomía peruana en las calles de Santiago y la construcción de espacios transnacionales y territorios. In Novick S, Stefoni C \& Hinojosa A (eds). Migraciones en América Latina, 211-227. Catálogos, Buenos Aires.

Stefoni C 2011. Migración, remesas y desarrollo. Estado del arte de la discusión y perspectivas. Polis 30, 495-521.

Stefoni C \& Fernández R 2011. Mujeres inmigrantes en el trabajo doméstico: entre el servilismo y los derechos. In Stefoni C (ed). Mujeres inmigrantes en Chile - Mano de obra o trabajadoras con derecho?, 43-72. Ediciones Alberto Hurtado, Santiago.

Sutton DE 2001. Remembrance of repasts: an anthropology of food and memory. Bloomsbury Academic, Oxford-New York.
Tapia-Ladino M 2012. Frontera y migración en el norte de a partir del análisis de los censos población: siglos XIX-XXI. Revista de Geografía Norte Grande 53, 177-198. http://dx.doi.org/10.4067/S0718-34022012000300011.

Thayer LE 2013. Expectativas de reconocimiento y estrategias de incorporación: la construcción de trayectorias degradadas en migrantes latinoamericanos residentes en la Región Metropolitana de Santiago. Polis (Santiago) 12: 35, 259-285. http://dx.doi.org/10.4067/S0718-65682013000200012.

Tijoux ME 2013. Niños(as) marcados por la inmigración peruana: estigma, sufrimientos, resistencias. Convergencia Revista de Ciencias Sociales 20: 61, 83-104.

Torres A \& Hidalgo R 2009. Los peruanos en Santiago de Chile: transformaciones urbanas y percepción de los inmigrantes. Polis (Santiago) 8: 22, 307-326. http://dx.doi.org/10.4067/S0718-65682009000100018.

Watson JL \& Caldwell ML 2005. The cultural politics of food and eating. Blackwell, Malden.

Wilk R 1999. Real Belizean food: building local identity in the transnational Caribbean. American Anthropologist 101: 2, 244-255. 